\title{
Seasonal and regional variations of the iodine content in milk from Federation of Bosnia and Herzegovina
}

\author{
doi: 10.15567/mljekarstvo.2015.0105 \\ Ćazim Crnkićl ${ }^{*}$, Max Haldimann ${ }^{2}$, Aida Hodžić $\hat{c}^{3}$, Husref Tahirović ${ }^{4}$ \\ ${ }^{1}$ Veterinary Faculty, Department of Animal Nutrition, University of Sarajevo, \\ Zmaja od Bosne 90, 71000 Sarajevo, Bosnia and Herzegovina \\ ${ }^{2}$ Federal Office of Public Health, Consumer Protection Directorate, \\ Schwarzenburgstrasse 165, CH-3097 Liebefeld, Switzerland \\ ${ }^{3}$ Veterinary Faculty, Department of Physiology, University of Sarajevo, \\ Zmaja od Bosne 90, 71000 Sarajevo, Bosnia and Herzegovina \\ ${ }^{4}$ University Clinical Centre Tuzla, Department of Paediatrics, \\ Trnovac bb, 75000 Tuzla, Bosnia and Herzegovina \\ Prispjelo - Received: 10.07.2014. \\ Prihvaćeno - Accepted: 16.01.2015.
}

\begin{abstract}
The aim of this study was to determine the iodine concentrations in raw cow's milk produced in Federation of Bosnia and Herzegovina $(\mathrm{B} \& \mathrm{H})$ and to evaluate the milk iodine contribution to the iodine intake in the $\mathrm{B} \& \mathrm{H}$ population. Milk samples $(\mathrm{n}=139)$ were taken from five regions during the spring, summer and winter season. Iodine concentrations were determined by the inductively coupled plasma mass spectrometry (ICP-MS) method. The mean ( \pm standard deviation) milk iodine concentration was $60.9 \pm 67.5 \mu \mathrm{g} / \mathrm{kg}$ and ranged from 4.4 to $378.7 \mu \mathrm{g} / \mathrm{kg}$. Winter milk had higher iodine content $(84.0 \pm 88.2 \mu \mathrm{g} / \mathrm{kg})$ than the spring $(45.3 \pm 46.7 \mu \mathrm{g} / \mathrm{kg})$ and summer milk $(51.3 \pm 51.0 \mu \mathrm{g} / \mathrm{kg})$, although two of five investigated regions did not follow this tendency and had the similar milk iodine content in all three seasons. Very low iodine concentrations $(<20 \mu \mathrm{g} / \mathrm{kg})$ were found in 41 milk samples from four regions indicating extensive iodine deficiency in dairy cows. Milk samples from the north-east of the country had much more iodine than samples from other regions in all seasons with no values below $20 \mu \mathrm{g} / \mathrm{kg}$. With the current average intake of $0.4 \mathrm{~L}$ milk per day, the milk contributes with $20 \%$ of the recommended iodine intake for humans, ranging from $6 \%$ to $72 \%$ depending on the season of the year and the region of the country. The results indicate the need for iodine supplementation of animal diets, as well as for increased milk consumption in human population.
\end{abstract}

Key words: dairy cows, iodine, raw milk, deficiency

\section{Introduction}

Iodine is an essential element to humans and animals. It is a constituent of the thyroid hormones and its deficiency causes goitre and may increase the risk for intellectual deficiency in affected populations. Iodine deficiency disorders represent a significant public health problem in 118 countries worldwide (Vitti et al., 2001). Among them, thirty-two European countries were still affected by mild to severe iodine deficiency in the late 1990s, including Eastern Europe as most severely affected region (Delange, 2002). Adequate iodine supply has a beneficial impact on health and iodine prophylaxis programmes are operating in many countries (Vitti et al., 2001).

Bosnia and Herzegovina (B\&H) also belongs to naturally iodine-deficient regions. Iodine deficiency has been eradicated in the country since 1953, when fortifying table salt with $3.75-11.25 \mathrm{mg}$ of iodide as 
potassium iodide per $\mathrm{kg}$ of sodium chloride started (Tahirovic et al., 2001). Nevertheless, some later studies showed an evidence of iodine deficiency (Filipovic and Siljak, 1974; Tahirovic et al., 2001) why health officials wanted to increase the iodine content of salt, as well as to activate health control programmes focusing on iodine status of schoolchildren (Tahirovic et al., 2001). On $25^{\text {th }}$ October 2001, Federation of B\&H government promulgated the new Regulations on Edible Salt Quality which requires iodization of salt with $20-30 \mathrm{mg}$ of iodine per $\mathrm{kg}$ of salt (Anonymous, 2001). Two years after the introduction of the new mandatory salt iodination it was determined that the increased iodine supplementation of salt in 2001 was successful and that Federation of $\mathrm{B} \& \mathrm{H}$ is presently iodine sufficient (Tahirovic et al., 2007).

However, humans obtain iodine from many other food sources besides salt. There has never been a systematic monitoring of the iodine intake from the $\mathrm{B} \& \mathrm{H}$ diet, and recommendations for salt iodization (Anonymous, 2001) were developed without general consideration of the iodine supply from other dietary sources like fish, eggs, meat and dairy products. Dairy products, eggs, and meat have traditionally been the principal foods of animal origin in the B\&H diet. Unless processed, meat has low iodine concentrations (Haldimann et al., 2005) and represents a poor source of dietary iodine for humans (Franke et al., 2008; Meyer et al., 2008). Unlike meat, dairy products and eggs may contain higher but variable amounts of iodine, depending on its content in animal feeds (EF SA, 2005).

Milk and dairy products became a major source of dietary iodine for humans in recent years. In Norway they contributed $55 \%$ of the iodine intake in adults and $70 \%$ in children (Dahl et al., 2004), and were considered as one of the principal sources of dietary iodine in other industrialized countries (Pennington, 1990; Lamand and Tressol, 1992; Vitti et al., 2001). Another important aspect of milk iodine is that its concentration is a useful tool in assessing the iodine intake of milk cows (Schöne et al., 2009; Borucki Castro et al., 2011) because high concentrations of iodine in animal diet increase iodine concentrations in milk (National Research Council, 2001; Schöne et al., 2009; Norouzian, 2011). Regarding the population, all iodine in the milk is available for nutrition (Binnerts, 1989) and increasing the iodine levels in cow's milk can be an efficient way to improve iodine supply to humans.

Although some important investigations on iodine status in human population, especially children, have been done in the past (Filipovic and Siljak, 1974; Tahirovic et al., 2001; Toromanovic and Tahirovic, 2004), data on the iodine nutrition of humans and animals in $\mathrm{B} \& \mathrm{H}$ are still very scarce. The relative contribution of different foods in the diet to the total daily intake of iodine is not known, except for table salt, because the iodine concentration in foods, including milk, or feeds has never been investigated.

The objective of this study was to evaluate the content of iodine in milk produced under B\&H conditions before its processing and to evaluate the effect of the season and region on iodine variability in raw milk. Also it was intended to evaluate the milk iodine contribution to the total iodine intake in the B\&H population.

\section{Materials and methods}

\section{Sampling}

Bulk samples of raw cow's milk were collected in accordance with standard ISO 707 (ISO, 2008). Samples were taken from five regular collecting areas for dairy processing as shown in Figure 1. These areas were covered by different milk processing factories which organize local milk collecting units for milk produced by small farmers and other producers. Region 1 (Rl) covered a part of the south-eastern B\&H near the Adriatic Sea. Regions 2 and 3 (R2, R3) were located in the middle of the country, and regions 4 and 5 (R4, R5) partially covered the north of the country on the eastern and western side, respectively. In every region milk was sampled during the early spring, summer and winter season. Thereby ten milk collecting units were randomly chosen, except in Rl where summer milk samples were not available, and nine samples were taken in the spring. Thus, the total number of milk samples was 139 . Number of samples from each region and season are presented in Figure 2. 


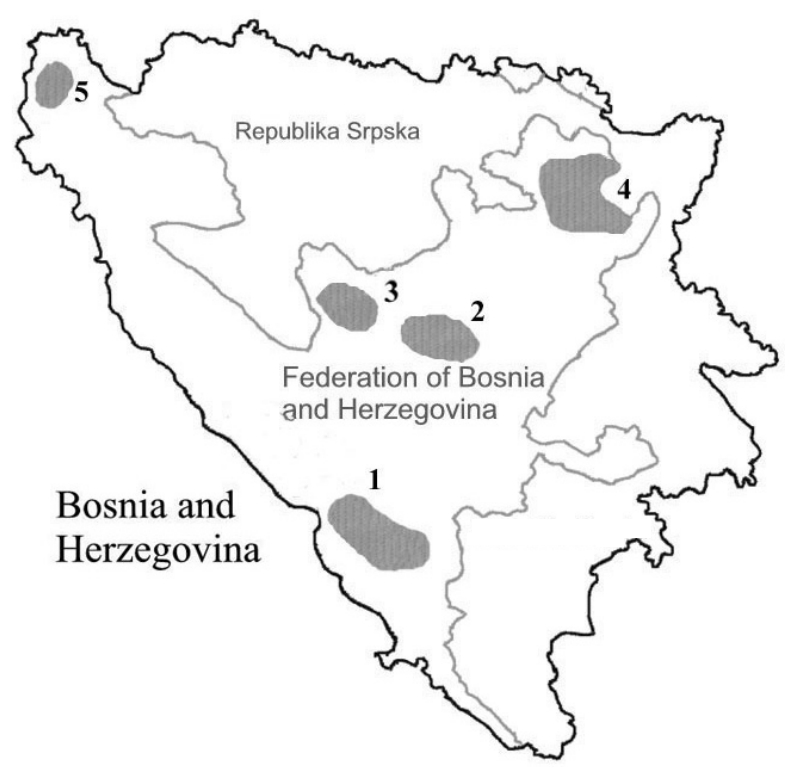

Figure 1. Regions in Federation of B\&H where milk iodine was investigated in the study

Approximately $20 \mathrm{~mL}$ of each samples was collected, packed into plastic bottles and stored at $-22^{\circ} \mathrm{C}$ with no preservative added. The frozen milk samples were sent from Veterinary Faculty - Sarajevo $(B \& H)$ to the Swiss Federal Office of Public Health for the inductively coupled plasma mass spectrometry (ICP-MS) measurement of iodine content.

\section{Samples preparation}

Portions of $2 \mathrm{~g}$ of the samples were extracted with tetramethyl ammonium hydroxide during $3 \mathrm{~h}$ at $90{ }^{\circ} \mathrm{C}$. After dilution with deionized water to a volume of $50 \mathrm{~mL}$ and sedimentation to remove the solid particles in suspension, aliquots of $2.5 \mathrm{~mL}$ were spiked with $20 \mathrm{ng}$ of ${ }^{129}$ I (NIST SRM 4949C, Iodine-129 radioactivity standard; National Institute of Standards and Technology, Gaithersburg, USA) and diluted with water to $5 \mathrm{~mL}$ for the final ICP-MS measurement.

\section{Determination of iodine content}

The ${ }^{129} \mathrm{I} /{ }^{127} \mathrm{I}$ ratios in the sample solutions were measured using an Element2 sector-field ICP-MS (Finnigan MAT, Bremen, Germany) at a resolution setting of $\mathrm{m} / \mathrm{m} \Delta=300$. The ICP-MS was equipped with a special high-solids nebulizer and a PFA (Scotttype) spray chamber. Isotope dilution evaluation of the data according to:

$$
m=n\left(R_{M}-R_{S}\right) M
$$

where $m$ is the total mass of natural iodine ${ }^{127} \mathrm{I}$ in the sample aliquot, $n$ is the number of moles of the radioisotope ${ }^{129} \mathrm{I}$ in the added spike, $R_{M}$ and $R_{S}$ are the molar ratios ${ }^{127} \mathrm{I} /{ }^{129} \mathrm{I}$ in the resulting mixture and added spike, respectively, and $M$ is the molar mass of the isotope ${ }^{127} \mathrm{I}$.

The limit of detection in isotope dilution analysis is given by the spike ratio according to:

$$
R_{L O D}>\left(\frac{{ }^{127} I}{{ }^{129} I}\right)_{\text {Spike }}+3 s
$$

where $s$ is the standard deviation of the spike ratio measurement. The detection limit for iodine in fresh milk was $0.2 \mu \mathrm{g} / \mathrm{kg}$. All measured samples were clearly above this limit value.

The whole milk reference material RM 8435 from NIST was included in each run $(n=7)$. The measured iodine concentration of $239 \pm 7.1 \mu \mathrm{g} / \mathrm{kg}$ agreed well with the reference concentration of $230 \pm 40 \mu \mathrm{g} / \mathrm{kg}$ at the $95 \%$ confidence interval (CI). All concentrations are given in $\mu$ g iodine per $\mathrm{kg}$ of milk as the samples ( $2.0 \mathrm{~g}$ ) have been weighed; however, the unit $\mu \mathrm{g} / \mathrm{kg}$ corresponds approximately to $\mu \mathrm{g} / \mathrm{L}$. 


\section{Statistical analysis}

One-way ANOVA with the factor "Region" and "Season" and Tukey pairwise mean comparisons were carried out using statistical software Minitab $14^{\circledR}$ (Minitab, 2003). P values below 0.05 were considered as significant. In the case of two groups' comparison, t-test for independent samples was used. ANOVA was computed based on logarithmically transformed values. Residual analysis was performed by generating normal probability plots, which indicated near normality after log transformation.

\section{Results and discussion}

Means \pm standard deviations (SD) of iodine concentrations in milk samples are shown in Table 1. Recorded values ranged from 4.4 to $378.7 \mu \mathrm{g} / \mathrm{kg}$ of milk with overall mean of $60.9 \pm 67.5 \mu \mathrm{g} / \mathrm{kg}$. Winter samples contained the highest levels of iodine in three of five tested regions. Regions R3 and R5 did not follow this tendency and had similar milk iodine concentrations in all three seasons. Concerning sampling regions all together, winter milk also had the highest mean concentration of iodine reaching almost as much as double values as spring and summer samples.

Comparing the regions, samples from $\mathrm{R} 4$ had much more iodine than samples from other four regions in all three seasons, ranging from 36.1 to 378.7 $\mu \mathrm{g} / \mathrm{kg}$ (Figure 2). The values were two to threefold higher comparing to season means, and three to sevenfold higher comparing to regional means (Table 1).

Useful biological indicators of iodine concentration in the soil of particular area are ruminants, which are fed roughages and water from the area where they are living (Herzig et al., 2003). About 80 to $90 \%$ of dietary iodine is absorbed and most of the iodine not taken up by the thyroid gland is excreted in urine and milk (National Research Council, 2001). Based on a number of published studies, National Research Council (2001) stated that milk normally contains from 30 to 300 $\mu \mathrm{g}$ iodine/L depending on its content in the diet of cows, and this relationship makes iodine content of milk an appropriate indicator of iodine status of the soil and animals.

Means of iodine concentration in milk samples in this study, for all regions and all seasons (Table 1), suggested normal values and adequate iodine supply in animals, but variations among individual samples were very wide (Figure 2). Only two samples had iodine concentration above $300 \mu \mathrm{g} / \mathrm{kg}$, while 41 samples (29\% of total) had iodine concentration below $20 \mu \mathrm{g} / \mathrm{kg}$. Values lower than $20 \mu \mathrm{g} / \mathrm{L}$ suggest iodine deficiency in the rations with no iodine supplements added (Herzig et al., 2003). Low values were found in all three seasons and in all regions except in R4 (Figure 2). Such findings might indicate possible iodine deficiency disorders in ruminants although field experiences suggest no apparent signs of it. However, subclinical and less recognized consequences of

Table 1. Means $( \pm \mathrm{SD})$ of iodine concentrations $(\mu \mathrm{g} / \mathrm{kg})$ in raw cow's milk produced in Federation of $\mathrm{B} \& \mathrm{H}^{*}$

\begin{tabular}{ccccccccc}
\hline & \multicolumn{2}{c}{ Spring } & \multicolumn{2}{c}{ Summer } & \multicolumn{2}{c}{ Winter } & \multicolumn{2}{c}{ All seasons } \\
\hline Region & mean & SD & mean & SD & mean & SD & mean & SD \\
\hline R1 & $23.7^{1, a}$ & 15.3 & - & - & $78.8^{2, b}$ & 55.7 & $52.7^{2}$ & 49.5 \\
\hline R2 & $32.0^{1}$ & 25.6 & $41.4^{1}$ & 43.3 & $60.9^{12}$ & 69.0 & $44.8^{12}$ & 49.1 \\
\hline R3 & $25.0^{1}$ & 8.9 & $18.5^{1}$ & 14.5 & $23.9^{1}$ & 11.9 & $22.5^{1}$ & 11.9 \\
\hline R4 & $114.5^{2, a}$ & 60.5 & $104.4^{2, a}$ & 53.4 & $215.6^{3, b}$ & 89.7 & $144.9^{3}$ & 84.4 \\
\hline R5 & $29.2^{1}$ & 16.8 & $40.9^{1}$ & 42.3 & $40.5^{12}$ & 18.1 & $36.9^{12}$ & 27.8 \\
\hline All regions & $45.3^{\mathrm{a}}$ & 46.7 & $51.3^{\mathrm{a}}$ & 51.0 & $84.0^{\mathrm{b}}$ & 88.2 & 60.9 & 67.5 \\
\hline
\end{tabular}

\footnotetext{
${ }^{*}$ regions and seasons have been compared by one-way ANOVAs and Tukey comparisons, except Rl row which was a t-test

$1,2,3$ - means in the same column with different superscript number differ significantly $(\mathrm{p}<0.05)$

$\mathrm{a}, \mathrm{b}-$ means in the same row with different superscript letter differ significantly $(\mathrm{p}<0.05)$
} 


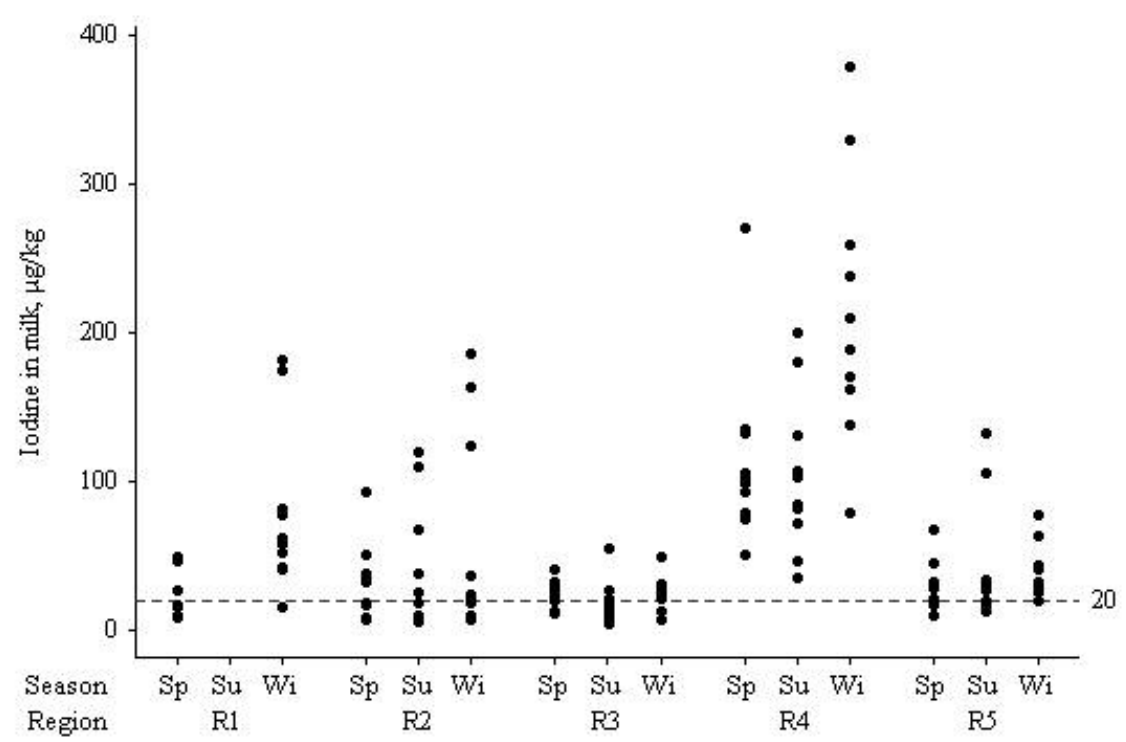

Figure 2. Iodine concentrations of individual milk samples from five different regions (R1-R5) of Federation of $\mathrm{B} \& \mathrm{H}$ in spring $(\mathrm{Sp})$, summer $(\mathrm{Su})$ and winter $(\mathrm{Wi})$ season.

iodine deficiency usually remain without diagnosed causes, including reproductive disturbances with reduced subsequent fertility in animals (Kursa et al., 2005). Low values of milk iodine recorded in this study clearly show extensive deficiency of iodine in animals in the most of country.

Winter milk would be expected to have higher iodine content than summer milk, as found in earlier studies (Lamand and Tressol, 1992; Lee et al., 1994; Larsen et al., 1999; Dahl et al., 2003; Travnicek et al., 2006; Brzóska et al., 2009). Use of iodine supplements in feed is usually more widespread in winter season and can be associated to increased iodine in the milk (Pennington, 1990; Dahl et al., 2003). Two investigated regions in this study showed no seasonal differences and had the lower means of milk iodine in comparison to other samples. Concerning that farming practice is similar throughout the country, it is not clear why samples from these two did not show the similar tendency in seasonal variations. Data on glucosinolates, plant compounds that interfere with iodine uptake by the thyroid gland (EFSA, 2008), could help to explain regional differences in part but their levels in animal feeds have never been investigated in $\mathrm{B} \& \mathrm{H}$.

The most significant findings in this study were related to milk samples from region $\mathrm{R} 4$ which had the highest iodine concentrations with no values less than
$20 \mu \mathrm{g} / \mathrm{kg}$ (Figure 2). Again, there are no important differences in feeding practice between the regions and authors expected lower iodine values, keeping in mind the distance from region R4 and the sea coast (Figure 1). Finally, sanitisation agents or disinfectant containing iodophores, which can contaminate milk with iodine (Herzig et al., 2003; Flachowsky et al., 2007), were generally not used in dairies in the country, and could not be considered as a possible cause of higher iodine in milk from the region. Iodine concentrations in crops and grasses decreased with distance to the sea, but the relation to the geological composition of the soil may be the predominant factor (Herzig et al., 2003). However, data on the geological composition of region R4 are lacking, and without knowledge of the iodine content in animal feeds and drinking water, reasons for high iodine content in milk from north-east of the country remain unclear. On the other hand, the obtained values showed a good status of iodine with no need for additional supplementation of animal diets that is beneficial from the human health point of view.

Average daily consumption of milk and dairy products in $\mathrm{B} \& \mathrm{H}$ population is equivalent to $0.4 \mathrm{~L}$ of milk with $3.6 \%$ of fat (Loza, 2007). With this amount of milk, daily consumption of iodine is expected to be about $30 \mu \mathrm{g}$ that is $20 \%$ of daily needs in adults, ranging from $9 \mu \mathrm{g}$ in region $\mathrm{R} 3$ during the 
summer to $108 \mu \mathrm{g}$ of iodine in region $\mathrm{R} 4$ during the winter (from $6 \%$ to $72 \%$ of daily needs) (WHOUNICEF-ICCIDD, 2001). Even on this low level of consumption, milk represents important source of dietary iodine for $\mathrm{B} \& \mathrm{H}$ population.

\section{Conclusions}

Analysis of iodine concentrations in milk in this study showed wide variations considering the season of the year and geographical origin of the milk. Some exceptions and conflicting data, especially from the north-east of the country, require further investigation on natural iodine sources and general status of iodine in the area including soil, water, plants and animal tissues. Developing strategy for use of iodine supplements in animal diets is needed where iodine deficiency in milk was recorded, keeping in mind the upper limit of $5 \mathrm{mg} \mathrm{I} / \mathrm{kg}$ feed of dairy cows (EU, 2005). Health education programs should also promote increased milk consumption. Reducing iodine deficiency in animals and increase of milk consumption would be expected to improve iodine status in human population, especially children and individuals who may not use table salt as a primary source of dietary iodine.

\section{Acknowledgement}

This work was supported by grant No. 04-394335/03 from Federal Ministry of Education and Science, Stjepana Radica 33, Mostar, Bosnia and Herzegovina.

\section{Sezonske i regionalne varijacije sadržaja joda u mlijeku u Federaciji Bosne i Hercegovine}

\section{Sažetak}

Cilj rada bio je utvrditi koncentraciju joda u sirovom kravljem mlijeku proizvedenom u Federaciji Bosne i Hercegovine $(\mathrm{BiH})$ te procijeniti udio mlijeka u ukupnoj konzumaciji joda kod $\mathrm{BiH}$ populacije. Uzorci mlijeka prikupljeni su iz pet različitih regija tijekom proljeća, ljeta i zime. Koncentracija joda u uzorcima određena je metodom ICP-MS. Srednja vrijednost ( \pm standardna devijacija) sadržaja joda $\mathrm{u}$ mlijeku iznosila je $60,9 \pm 67,5 \mu \mathrm{g} / \mathrm{kg}$ i varirala od 4,4 do $378,7 \mu \mathrm{g} / \mathrm{kg}$. Zimsko mlijeko sadržavalo je više joda $(84,0 \pm 88,2 \mu \mathrm{g} / \mathrm{kg})$ nego proljetno $(45,3 \pm 46,7$ $\mu \mathrm{g} / \mathrm{kg})$ i ljetno mlijeko $(51,3 \pm 51,0 \mu \mathrm{g} / \mathrm{kg})$, iako u dvije od pet istraživanih regija nije postojala ovakva tendencija a sadržaj joda u mlijeku bio je sličan u sve tri sezone. Vrlo niske koncentracije joda (ispod 20 $\mu \mathrm{g} / \mathrm{kg}$ ) utvrđene su u 41 uzorku, ukazujući na raširen deficit joda kod muznih krava. Mlijeko iz sjeveroistočnog dijela zemlje imalo je znatno veći sadržaj joda nego mlijeko iz preostale četiri regije u sve tri sezone. U svim uzorcima iz te regije sadržaj joda bio je veći od $20 \mu \mathrm{g} / \mathrm{kg}$. Uz trenutno postojeću prosječnu konzumaciju od 0,4 L dnevno, mlijeko sudjeluje s 20 $\%$ u preporučenom dnevnom unosu joda za ljude, varirajući od $6 \%$ do $72 \%$, ovisno o sezoni godine i dijelu zemlje. Rezultati ukazuju na potrebu dodatnog obogaćivanja obroka životinja jodom, kao i na potrebu povećanja konzumacije mlijeka kod ljudske populacije.

Ključne riječi: muzne krave, jod, sirovo mlijeko, deficit

\section{References}

1. Anonymous (2001): The Rulebook on edible salt quality. Official Register of Federation of B\&H, No.8, 10221023.

2. Binnerts, W.T. (1989): Milk analysis for the iodine status of dairy cows, Zeitschrift fur die Gesamte Hygiene und Ihre Grenzgebiete 35 (1), 12-15.

3. Borucki Castro, S.I., Lacasse, P., Fouquet, A., Beraldin, F., Robichaud, A., Berthiaume, R. (2011): Short communication: Feed iodine concentrations on farms with contrasting levels of iodine in milk, Journal of Dairy Science 94 (9), 4684-4689. doi: dx.doi.org/10.3168/jds.2010-3714

4. Brzóska, F., Szybiński, Z., Śliwiński, B. (2009): Iodine concentration in Polish milk: variations due to season and region. Polish Journal of Endocrinology 60 (6), 449-454.

5. Dahl, L., Opsahl, J.A., Meltzer, H.M., Julshamn, K. (2003): Iodine concentration in Norwegian milk and dairy products, British Journal of Nutrition 90 (3), 679-685. doi: dx.doi.org/10.1079/BJN2003921

6. Dahl, L., Johansson, L., Julshamn, K., Meltzer, H.M. (2004): The iodine content of Norwegian foods and diets, Public Health Nutrition 7 (4), 569-576. doi: dx.doi.org/10.1079/PHN2003554 
7. Delange, F. (2002): Iodinedeficiency in Europeand itsconsequences: an update, European Journal of Nuclear Medicine and Molecular Imaging 29 (Suppl.2), S404-S416. doi: dx.doi.org/10.1007/s00259-002-0812-7

8. EFSA (2005): Opinion of the Scientific Panel on Additives and Products or Substances used in Animal Feed on the request from the Commission on the use of iodine in feedingstuffs, The EFSA Journal 168, 1-42.

9. EFSA (2008): Opinion of the Scientific Panel on Contaminants in the Food Chain on a request from the European Commission on glucosinolates as undesirable substances in animal feed, The EFSA Journal 590, 1-76.

10. EU Commission Regulation (EC) No 1459/2005. Official Journal of the European Union, L 233, 8-10.

11. Filipovic, A., Siljak, D. (1974): Incidence of goiter in 5 hyperendemic centres of Bosnia and Herzegovina on a sample of schoolchildren 20 years after prevention using iodine, Medical Archives 28 (5), 471-479.

12. Flachowsky, G., Schöne, F., Leiterer, M., Bemmann, D., Spolders, M., Lebzien, P. (2007): Influence of an iodine depletion period and teat dipping on the iodine concentration in serum and milk of cows, Journal of Animal and Feed Science 16 (1), 18-25.

13. Franke, K., Schöne, F., Berk, A., Leiterer, M., Flachowsky, G. (2008): Influence of dietary iodine on the iodine content of pork and the distribution of the trace element in the body, European Journal of Nutrition 47 (1), 40-46. doi: dx.doi.org/10.1007/s00394-007-0694-3

14. Haldimann, M., Alt, A., Blanc, A., Dufossé, K. (2005): Iodine content of food groups, Journal of Food Composition and Analysis 18 (6), 461-471. doi: dx.doi.org/10.1016/j.jfca.2004.06.003

15. Herzig, I., Poul, J., Pisarikova, B., Gopfert, E. (2003): Milk iodine concentration in cows treated orally or intramuscularly with a single dose of iodinated fatty acid esters, Veterinarni Medicina 48 (6), 155-162.

16. ISO (2008): Milk and milk products-Guidance on sampling, International Organization for Standardization ISO 707, 2008.

17. Kursa, J., Herzig, I., Travnicek, J., Kroupova, V. (2005): Milk as a Food Source of Iodine for Human Consumption in the Czech Republic, Acta Veterinaria Brno 74 (2), 255-264. doi: dx.doi.org/10.2754/avb200574020255

18. Lamand, M., Tressol, J.C. (1992): Contribution of milk to iodine intake in France, Biological Trace Element Research 32 (1), 245-251. doi: dx.doi.org/10.1007/BF02784607

19. Larsen, E.H., Knuthsen, P., Hansen, M. (1999): Seasonal and regional variations of iodine in Danish dairy products determined by inductively coupled plasma mass spectrometry, Journal of Analytical Atomic Spectrometry 14 (1), 41-44. doi: dx.doi.org/10.1039/a806642f

20. Lee, S.M., Lewis, J., Buss, D.H. (1994): Iodine in British foods and diets, British Journal of Nutrition 72 (3), 435-446. doi: dx.doi.org/10.1079/BJN19940045
21. Loza, D. (2007): Production, collecting, processing and trade of milk in Bosnia and Herzegovina in the year 2006. Milkprocessing d.o.o. Sarajevo (In Bosnian).

22. Meyer, U., Weigel, K., Schöne, F., Leiterer, M., Flachowsky, G. (2008): Effect of dietary iodine on growth and iodine status of growing fattening bulls, Livestock Science 115 (2), 219-225. doi: dx.doi.org/10.1016/j.livsci.2007.07.013

23. MINITAB Statistical Software (2003): Release 14 for Windows. State College, Pennsylvania. Copyright ${ }^{\odot}$ 2000-2003 Minitab Inc.

24. National Research Council (2001): Nutrient requirements of dairy cattle. $7^{\text {th }}$ rev.ed. National Academy Press, Washington, DC, pp 136-138.

25. Norouzian, M.A. (2011): Iodine in raw and pasteurized milk of dairy cows fed different amounts of potassium iodide, Biological Trace Element Research 139 (2), 160-167. doi: dx.doi.org/10.1007/s12011-010-8651-z

26. Pennington, J.A.T. (1990): Iodine concentrations in US milk: Variation due to time, season, and region, Journal of Dairy Science 73 (12), 3421-3427. doi: dx.doi.org/10.3168/jds.S0022-0302(90)79039-X

27. Schöne, F., Leiterer, M., Lebzien, P., Bemmann, D., Spolders, M., Flachowsky, G. (2009): Iodine concentration of milk in a dose-response study with dairy cows and implications for consumer iodine intake, Journal of Trace Elements in Medicine and Biology 23 (2), 84-92. doi: dx.doi.org/10.1016/j.jtemb.2009.02.004

28. Tahirovic, H., Toromanovic, A., Hadzibegic, N. (2001): Assessment of current status of iodine prophylaxis in Bosnia and Herzegovina Federation, Journal of Pediatric Endocrinology \& Metabolism 14 (8), 1139-1144.

29. Tahirovic, H., Imsiragic-Zovko, S., Toromanovic, A., Begic, L. (2007): Assesment of the success of implementation of new Rule book on salt iodination in Federation of Bosnia and Herzegovina, Journal of Endocrinological Investigation 30 (1), 9-12. doi: dx.doi.org/10.1007/BF03347389

30. Toromanovic, A., Tahirovic, H. (2004): Thyroid volume and urinary iodine excretion in schoolchildren in North-Eastern Bosnia, European Journal of Pediatrics 163 (4-5), 270-271. doi: dx.doi.org/10.1007/s00431-003-1286-8

31. Travnicek, J., Herzig, I., Kursa, J., Kroupova, V., Navratilova, M. (2006): Iodine content in raw milk, Veterinarni Medicina 51 (9), 448-453.

32. Vitti, P., Rago, T., Aghini-Lombardi, F., Pinchera, A. (2001): Iodine deficiency disorders in Europe, Public Health Nutrition 4 (2B), 529-535. doi: dx.doi.org/10.1079/PHN2001138

33. WHO-UNICEF-ICCIDD (2001): Assessment of iodine deficiency disorders and monitoring their elimination. Geneva: WHO, Document WHO/NHD/01.1., pp $1-106$. 